\title{
t.
}

\section{USGS Water Data for Washington}

News New Mapper and Experimental Real-Time Wab Service - updated August 2009

\section{USGS Water Data for Washington}

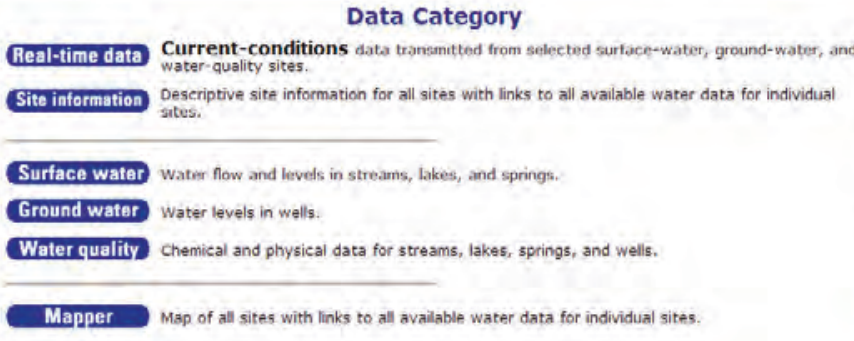

These pages provide access to water resources data collected in the State of Washingthe continuing work to assess the water resources of the many federal, state and local a concies. Tribal Nations, are provided for the use of the utilities, companies and the public with interests in the water resources in Washington. These pages include ground water and surface water data - and the associated waternormally published in Annual Data Reports, but can be publlshed in investloative reports. Additional information is available from the Web pages of the Washington Water Science Center.

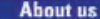

Figure 1. Screen capture of NWISWeb home page for Washington.

The U.S. Geological Survey (USGS) has been investigating the water resources of Washington State since the latter part of the 19th century. During this time, demand for water has evolved from primarily domestic and stock needs to the current complex requirements for public-water supplies, irrigation, power generation, navigation, ecological needs, and numerous other uses. Water-resource data collected by the USGS in Washington have been, or soon will be, published by the USGS Washington Water Science Center (WAWSC) in numerous data and interpretive reports. Most of these reports are available online at the WAWSC web page

http://wa.water.usgs.gov/pubs/.

\section{Water Resource Data}

Water-resource data collected by the USGS are stored for internal use in the USGS National Water Information System (NWIS). To disseminate these data to the public, the USGS maintains a publicly accessible version of NWIS known as NWISWeb that can be accessed at

\section{http://waterdata.usgs.gov/wa/nwis/.}

NWISWeb provides public access to several million items of historical and real-time water-resource data, which can be viewed and downloaded in various formats. As shown in figure 1, NWISWeb allows access to five categories of water resource data:

\section{- Real-time data \\ - Site information \\ - Surface water \\ - Groundwater \\ - Water quality}

In addition to water-resource data collected by the USGS, NWIS and NWISWeb include data collected by many other agencies, tribal nations, and organizations. However, neither database includes all the water-resource data collected in Washington State.

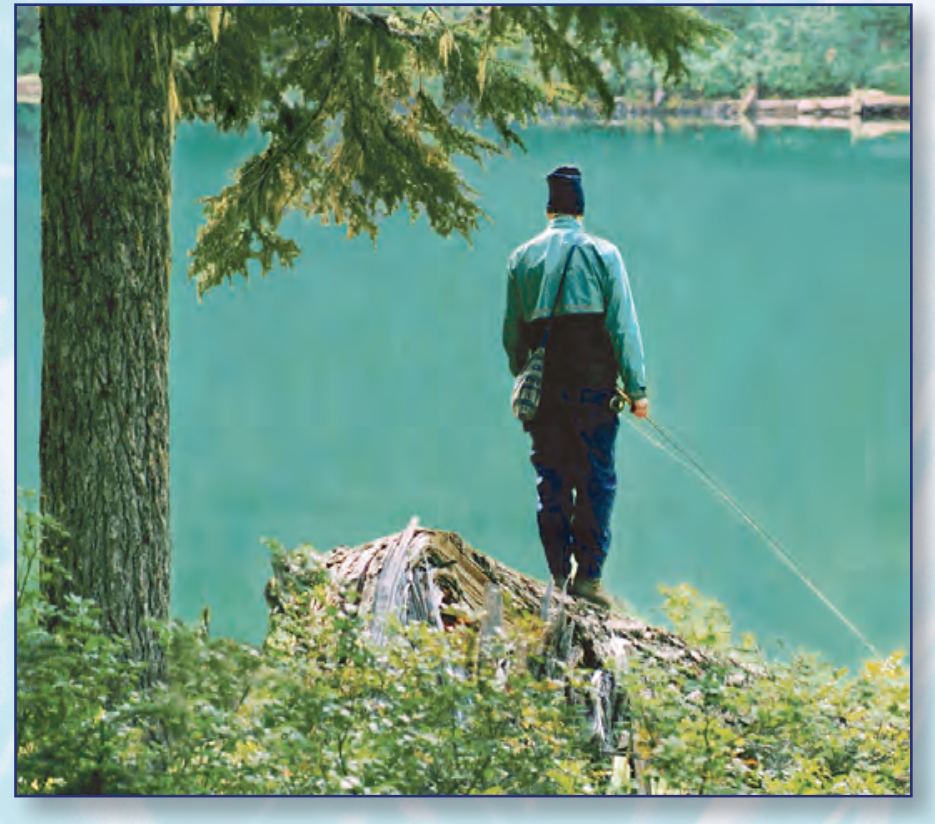

Real-Time Data

Real-time data are time-series data recorded at fixed intervals by automated equipment, are transmitted by satellite telemetry, and represent the most current hydrologic conditions. Real-time data for Washington are available at

\section{http://waterdata.usgs.gov/wa/nwis/rt,}

and the web pages listed in the Surface water, Groundwater, and Water quality sections. The real-time web-page contains streamflow, reservoir, water-quality, meteorological, and groundwater data from about 300 sites, including about 240 sites that have satellite telemetry for real-time data and another 20 sites that use other communications methods to transmit near real-time data. 


\section{Water Quality}

Water-quality data for Washington are available at http://waterdata.usgs.gov/wa/nwis/qw.

The water-quality web page contains data for nearly 15,000 sites in Washington, including 12,000 groundwater sites, 2,700 surface-water sites, and 500 miscellaneous sites such as subsurface drains and soil-test holes. These data include:

- Real-time water-quality data from 28 automated sites

- Daily water-quality data for 55 sites

- Daily, monthly, and annual statistics of water-quality data for 39 sites

- Field and laboratory analyses of chemical, physical, biological, and other environmental properties for about 15,000 sites

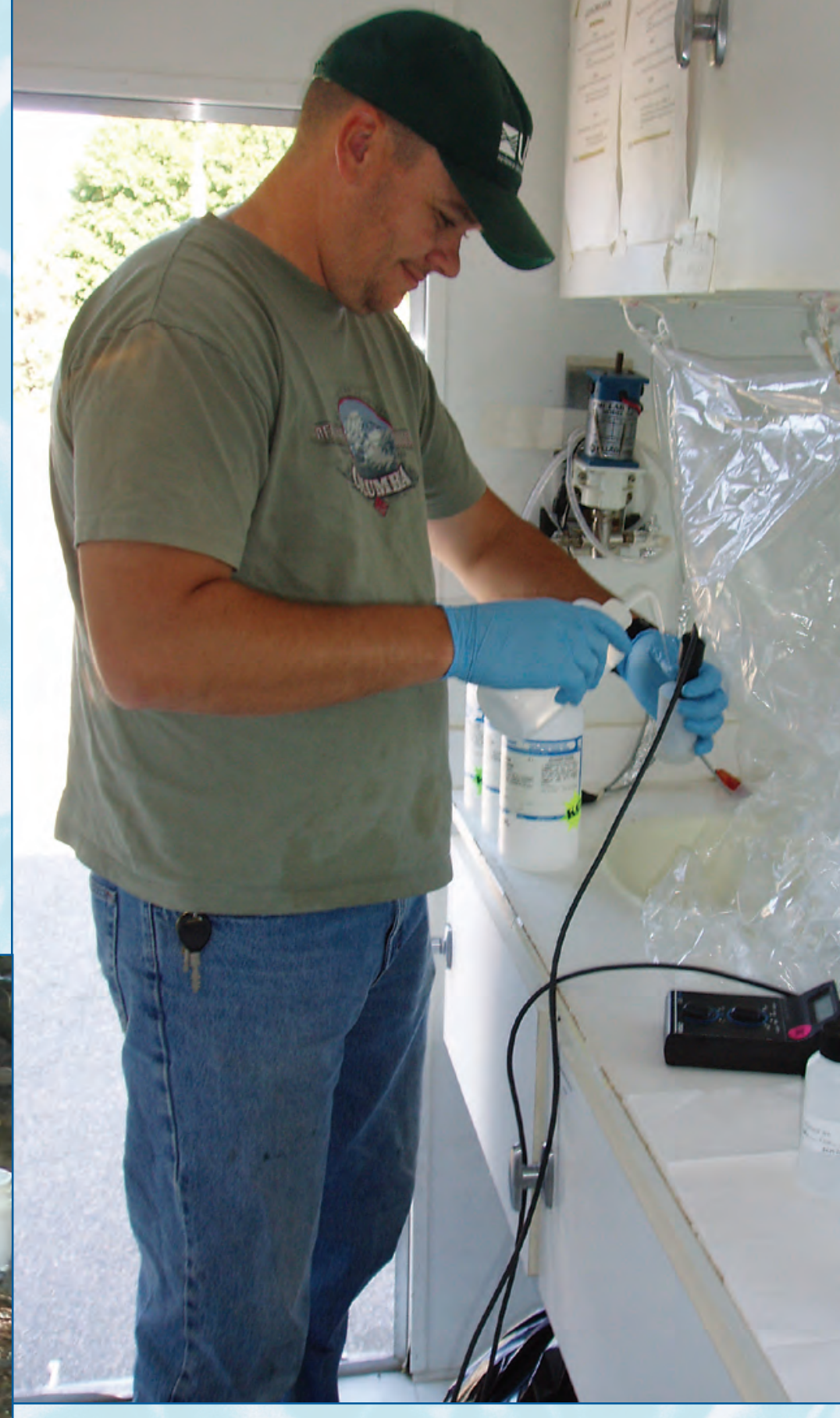

\section{Water Use}

Since 1950, the USGS has, at 5-year intervals, compiled and published data on the amount of water used in homes, businesses, industries, and on farms throughout the United States. The water-use data for Washington State can be accessed at the WAWSC web page at http://wa.water.usgs.gov/data/wuse/. 


\section{Site Identification}

Every site in NWIS and NWISWeb is assigned a unique site identification number (site ID) and a unique site or station name. For groundwater, springs, and most non-surface-water sites the site ID is a 15-digit number formed from the initial latitude and longitude of the site in degrees, minutes, and seconds, and a 2-digit sequence number. The first 6 digits of the site number are the latitude, the 7th through 13th digits are the longitude, and the 14th and 15th digits are sequence numbers used to distinguish between sites at the same location. Leading zeros are used as needed so the site number will not contain blank spaces. Although the site number is based on the initial latitude and longitude of the site, once assigned, the number is used only as an identification number; it has no location significance and cannot be changed.

The site name for a ground-water site in Washington is based on the site location in terms of the Public Land Survey rectangular grid system (fig. 2). For example, in site name $25 \mathrm{~N} / 45 \mathrm{E}-11 \mathrm{~K} 01,25 \mathrm{~N}$ indicates the township north of the Willamette base line; 45E indicates the range east of the Willamette meridian; 11 indicates the section; and $\mathrm{K}$ indicates the 40 -acre tract (quarter-quarter) within the section. The number following the section (01) is a sequence number that indicates the order in which wells in the same quarter-quarter were identified for entry into the database. A suffix after the sequence number indicates that a well has been deepened (D1) or reconditioned (R1) after its initial construction. The suffix S identifies a site as a spring rather than a well.

Figure 2. Well numbering system in Washington.

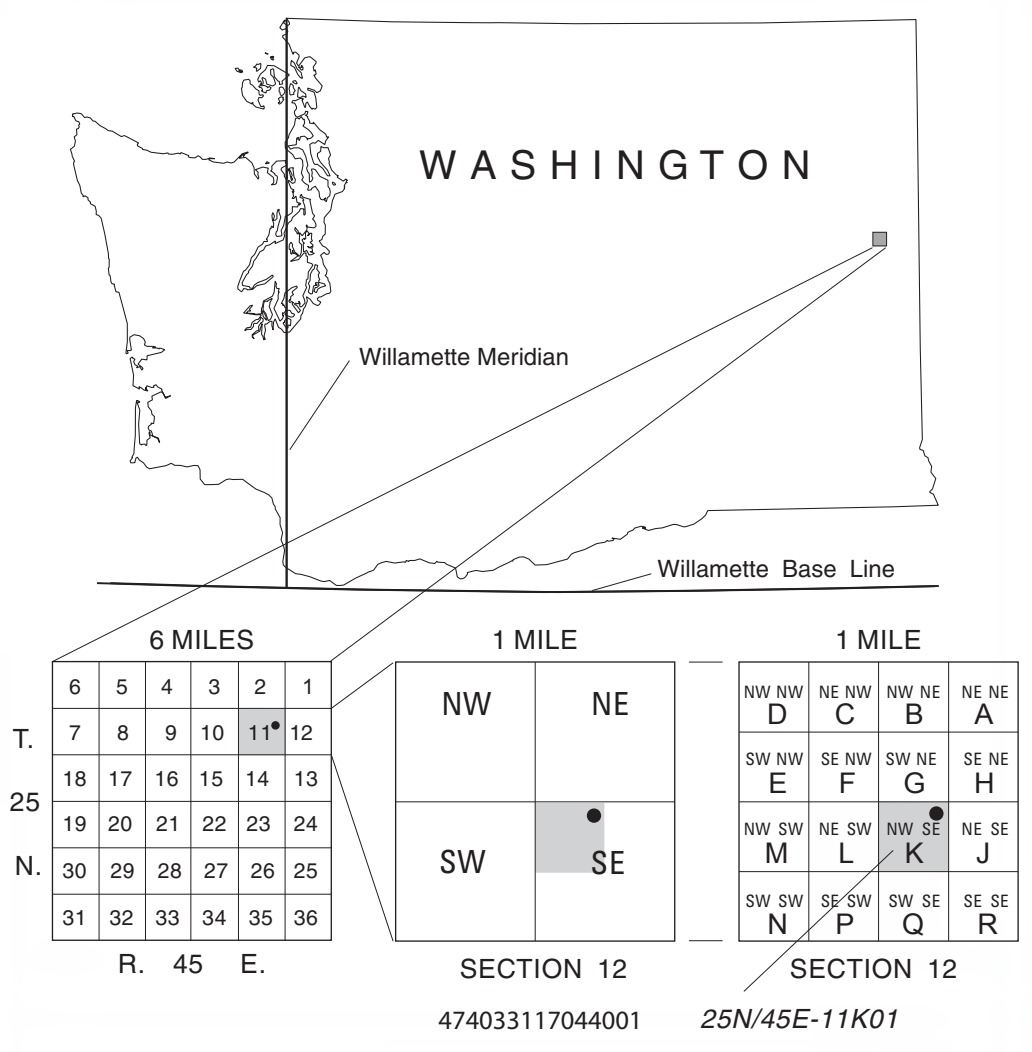

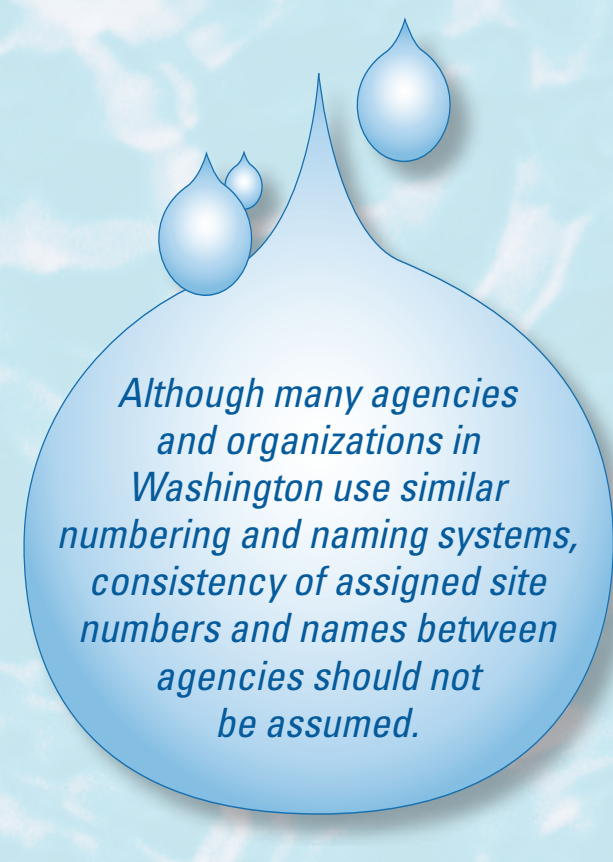

For surface-water and other sites where water is exposed on the land surface, the site ID is typically an 8 to 10 digit downstream order number, which locates the site in terms of the site's distance from the source (upstream end) of the surface-water body. For surface-water sites the station name consists of five parts: (1) the feature name (stream, canal, or reservoir); (2) the generic name ("River," "Lake," "tunnel" and so on); (3) the term to indicate location ("at," "above," "below," "near," and so on); (4) the place name (city, town, or major feature); and (5) the State or States where the reference place name is located. For example: SPOKANE RIVER BELOW UPRIVER DAM AT SPOKANE, WA.

\section{Water Data for Other States}

Publicly viewable water-resource data for other states are available at

http://waterdata.usgs.gov/wa/nwis/nwis by using the navigation buttons in the lower left corner of the banner to select the data category and geographic area of interest.

\section{Public Inquires and Data Requests}

Inquires and requests for data and reports may be made on-line at the WAWSC web-page,

http://wa.water.usgs.gov/pubinfo/

Or by contacting the Public Information Officer, 253-552-1635

Washington Water Science Center at:

U.S. Geological Survey

Washington Water Science Center

934 Broadway, Suite 300

Tacoma, Washington 98402

http://wa.water.usgs.gov/ 